\title{
Coeloconic Sensilla on the Antennae of the Yellow Fever Mosquito, Aedes aegypti (L.) $)^{1}$
}

Of the investigators to examine closely the sensory structures on the antennal flagellum of culicine mosquitoes $^{2-11}$ none found coeloconic sensilla, pegs sunken in pits, whereas these organs are frequent on anopheline antennae ${ }^{5,7,12}$. Evidence from fine structure studies presented herein reports the existence of inconspicuous sensilla coeloconica on the antennae of female Aedes aegypti (L.), demonstrating that both subfamilies of the Culicidae have such sensory structures.

Materials and methods. Antennae of female A. aegypti were fixed overnight in Karnovsky's fixative ${ }^{13}$, washed in $0.05 M$ Sorenson's $10 \%$ sucrose buffer, $\mathrm{pH} 7$, and post fixed in $1 \%$ OsO4 in veronal acetate buffer. The tissue was dehydrated through ethanol, embedded in Spurr's epoxy medium ${ }^{14}$, and stained with uranyl acetate and lead citrate.

Results. In sections of flagellar segment 12 , just proximal to terminal segment 13 , a typical coeloconic sensillum was observed (Figure). The peg, which is approximately 2.5. $\mu \mathrm{m}$ long and tapers from a base $1.4 \mu \mathrm{m}$ in diameter to a tip $0.35 \mu \mathrm{m}$ in diameter, is set in a pit with an opening slightly less than $1 \mu \mathrm{m}$. Coeloconic sensilla on anopheline antennae are several times larger than the one described here. A cuticular sheath encases the dendrite(s) and foldings of the tormogen cell membrane occur around the cuticularized pit.

Of the investigations on the antennal sensory structures of female $A$. aegypti $i^{\mathbf{4}, \boldsymbol{6}-8}$, only one ${ }^{8}$ reported the existence of small, spberical structures with hyaline properties on flagellar segments 1,10 and 12 . These structures were called campaniform organs and when similar sensilla were observed on the antennae of a variety of Culex species ${ }^{9-11}$, usage of the same term was continued. However, it is probable that the coeloconic type of sensillum reported in this paper is the 'campaniform organ' which was originally misidentified due to the limitations of the light

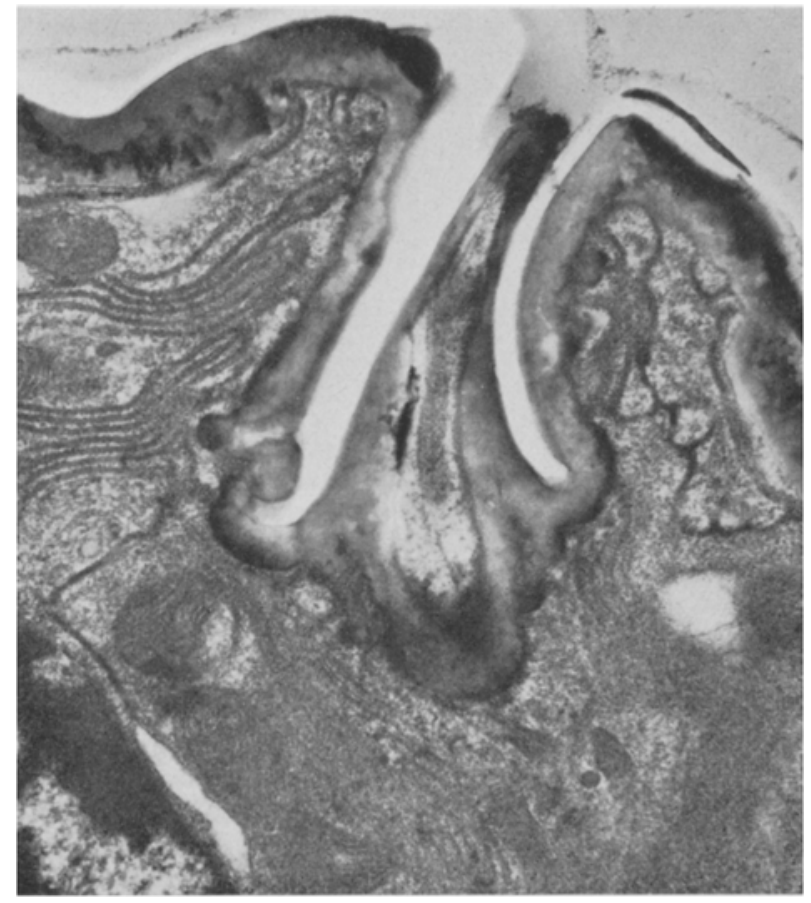

Section through flagellar segment 12 of female Aedes aegypti showing coeloconic sensillum, $\times 64,000$. microscope in observing such small structures. This conclusion is substantiated by finding the coeloconic sensillum in the same area of the flagellum as reported for the campan iform organ ${ }^{8}$. Furthermore, upon subsequent light microscope investigations by ourselves, we did not observe any irregularity of the cuticle in the region of the coeloconic sensillum other than that associated with the 'campaniform organ' which would account for the presence of the coeloconic sensillum.

Coeloconic sensilla have been shown electrophysiologically to have several functions. On Apis mellifera they contain neurons which respond to carbon dioxide and temperature and/or humidity ${ }^{15}$. Certain coeloconic sensilla on Locustra migratoria are sensitive to leaf extracts while others respond to temperature and humidity ${ }^{16-18}$. Although the function of the coeloconic sensilla on $A$. aegypti is not known, their existance is of consequence in the understanding of mosquito behavior, especially with regards to the increasing interest in the function of mosquito sensory receptors in perceiving attractants and repellents ${ }^{19-22}$.

Zusammenfassung. Elektronenoptischer Nachweis von Sensilla coeloconica bei Aedes aegypti-«Weibchen» was beweist, dass nicht nur Culicinae, sondern auch Anophelinae Sinnesstrukturen besitzen.

\section{S. B. McIver and S. A. Hutchinson}

Department of Parasitology,

School of Hygiene, University of Toronto,

Toronto 181 (Ontario, Canada), 17 September 1971.
1 Supported by Medical Research Council Grant No. MA 2909.

2 K. M. Sмıтн, Proc. zool. Soc., Lond. Parts I and II, 31 (1919).

${ }^{3}$ L. M. Roth, Ann, ent. Soc. Am. 44, 59 (1951).

${ }^{4}$ L. M. Roth and E. R. Willis, J. Morphl. 91, 1 (1952).

${ }^{5}$ L. V. Ivanova, in Voprosy obsheshey zoologii i Meditsinskoy parazitologii (Ed. P. G. Sergiev; Nedgiz, Moscow 1962), p. 496.

${ }^{6}$ E. H. Slifer and S. S. Sekhon, J. Morph. 111, 49 (1962).

7 C. C. Steward and C. E. Atwood, Can. J. Zool. 41, 577 (1963).

${ }^{8}$ I. A. H. Ismail, Acta trop. 27, 155 (1964).

9 S. B. McIver, Ann. ent. Soc. Am. 62, 1455 (1969).

10 S. B. McIver, Can. Ent. 102, 1258 (1970).

11 S. B. McIver, Can. J. Zool. 49, 235 (1971).

12 I. A. H. Ismail, Acta trop. 19, 1 (1962).

${ }_{13}$ M. J. Karnovsky, J. Cell Biol, 27, 137A (1965).

14 A. R. Spurr, J. Ultrastruct. Res. 26, 31 (1969).

15 V. Lacher, Z. vergl. Physiol. 48, 587 (1964).

16 J. Boeckh, K. E. Kaissling and D. Schneider, Cold Spring Harb. Symp. quant. Biol. 30, 263 (1965).

17 J. Bоескн, Proc. 2nd Int. Symp. Olfaction Taste, Pergamon Press, Oxford (1967), p. 721.

$18 \mathrm{~J}$. BoEckH, Z. vergl. Physiol. 13, 1461 (1967).

19 V. Lacher, J. Insect Physiol. 13, 1461 (1967).

20 V. LACHER, Experientia 25, 768 (1969).

21 V. LACher, J. Insect Physiol. 17, 507 (1971).

${ }^{22}$ F. E. Kellogg, J. Insect Physiol. 16, 99 (1970). 